\title{
Nicotine on rat TRAM flap ${ }^{1}$
}

\author{
Nicotina em retalho TRAM em ratos
}

\author{
Pedro Bins Ely, Ludmila Aimi Kobayashi", José Humberto Oliveira Campos ${ }^{\mathrm{III}}$, Heitor Carvalho Gomes ${ }^{\mathrm{IV}}$, Yara Juliano ${ }^{\mathrm{V}}$, Lydia \\ Masako Ferreira ${ }^{\mathrm{VI}}$ \\ ${ }^{I} \mathrm{PhD}$, Plastic Surgery, Unit Santa Casa de Porto Alegre, Rio Grande do Sul, Brazil. \\ ${ }^{\text {II }}$ Resident, Plastic Surgery Division, Department of Surgery, UNIFESP, Sao Paulo, Brazil. \\ ${ }^{\text {III }} \mathrm{PhD}$, Head of Operative Technique and Experimental Surgery Division, Department of Surgery, Escola Bahiana de Medicina, Bahia, Brazil. \\ ${ }^{\text {IV }} \mathrm{PhD}$, Assistant Professor, Plastic Surgery Division, Department of Surgery, UNIFESP, Sao Paulo, Brazil. \\ ${ }^{v}$ PhD, Full Professor, Department of Epidemiology, UNIFESP, Sao Paulo, Brazil. \\ ${ }^{V I} \mathrm{PhD}$, Full Professor, Head of Plastic Surgery Division and Chairwoman of Department of Surgery, UNIFESP, Sao Paulo, Brazil.
}

\begin{abstract}
Purpose: The transverse rectus abdominis myocutaneous (TRAM) flap is one of the preferential techniques used in breast reconstruction following mastectomy. Nicotine has a detrimental effect on cutaneous flap survival; although there are no experimental studies proving this effect on musculocutaneous flaps. The aim of this study is to verify the effect of nicotine on the rat TRAM flap. Methods: 30 Wistar EPM-1 rats were randomly distributed in two groups: control and experimental. The animals of the control group received saline solution injected subcutaneously, in a volume of $0.2 \mathrm{ml}$, twice a day, during 28 days in the preoperative period. The animals of the experimental group were treated with nicotine, injected subcutaneously, in a dose of $2 \mathrm{mg} / \mathrm{kg}$ twice a day, during 28 days in the preoperative period. All the animals were submitted to the caudally based, right unipedicled TRAM flap. 48 hours after the procedure, a study of the viable area of the flap was done through photographic documentation. Statistical analysis was performed with nonparametric Mann-Whitney’s test. Results: The experimental group had significantly greater area of necrosis when compared with the control group $(\mathrm{p}<0.001)$. Conclusion: Nicotine increased the area of necrosis of the TRAM flap, in rats.
\end{abstract}

Key words: Surgical Flaps. Nicotine. Rectus Abdominis. Surgery, Plastic. Rats.

\section{RESUMO}

Objetivos: O retalho musculocutâneo transverso do músculo reto do abdome (TRAM) é uma das principais opções na reconstrução do relevo mamário pós-mastectomia. A nicotina tem efeito deletério na viabilidade de retalhos cutâneos; porém, não foram encontrados trabalhos experimentais comprovando este efeito em retalhos musculocutâneos. O objetivo deste trabalho é investigar o efeito da nicotina na viabilidade do retalho TRAM, em ratos. Métodos: Foram utilizados 30 ratos da linhagem Wistar EPM-1. Os animais foram distribuídos aleatoriamente em dois grupos: controle e experimento. Os animais do grupo controle foram tratados com solução salina injetada no tecido celular subcutâneo num volume de $0,2 \mathrm{ml}$, duas vezes ao dia, durante 28 dias no período pré-operatório. Os animais do grupo experimento foram tratados com nicotina injetada no tecido celular subcutâneo em uma dose de $2 \mathrm{mg} / \mathrm{kg} / 2$ vezes ao dia, durante 28 dias no período pré-operatório. Todos os animais foram submetidos ao procedimento do retalho TRAM de base caudal unilateral à direita (pedículo não dominante). 48 horas depois, foi feita a avaliação da área viável de superfície do retalho, por documentação fotográfica. Para análise dos resultados foram utilizados testes não paramétricos: Mann-Whitney. Resultados: O grupo experimento apresentou uma área de necrose maior, quando comparado com o grupo controle $(\mathrm{p}<0,001)$. Conclusão: A nicotina aumentou a área de necrose do retalho TRAM, em ratos.

Descritores: Retalhos Cirúrgicos. Nicotina. Reto do Abdome. Cirurgia Plástica. Ratos.

${ }^{1}$ Research performed at Plastic Surgery Division, Department of Surgery, Federal University of Sao Paulo (UNIFESP), Brazil.

\section{Introduction}

Post-mastectomy breast reconstruction have been the object of a series of studies by plastic surgeons and mastologists. Among the several techniques proposed, the Transverse Rectus Abdominis Musculocutaneous flap (TRAM flap) have been the preferred choice in many services that work in the area of reconstructive surgery ${ }^{1}$.
To study variants of the TRAM flap procedure and the effect of drugs in its perfusion and viability, animal models were developed, including pig $^{2}$, mouse $^{3}$ and rat ${ }^{4,5,6,7}$. These animal models set the stage for further studies about the TRAM flap ${ }^{8}$.

Nicotine has a deleterious effect in the viability of cutaneous flaps $^{9,10}$; however, there are no experimental works showing this effect on musculocutaneous flaps. The objective of this study was to investigate the effect of nicotine on the viability of the TRAM flap, in rats. 


\section{Methods}

The effect of nicotine was investigated using the rat TRAM flap model ${ }^{5}$. Thirty male Wistar EPM-1 rats (Rattus norvegicus albinus, Rodentia mammalia), adults, weighting 240 to $290 \mathrm{~g}$ from the Center of Development of Experimental Models for Medicine and Biology (CEDEME) of the UNIFESP were studied. All surgery procedures were performed according to the guidelines and protocols of the care and use committee and laboratory standards of UNIFESP. This research was approved by the Ethics and Research Committee of the UNIFESP. The animals were kept in individual cages, in a room with a 12-hour light/dark cycle and fed standard rat chow and water ad libidum.

The animals were randomly distributed in two groups: Control and Experimental. The Control group was treated with saline injected into the subcutaneous tissue in a volume of $0.2 \mathrm{ml}$, twice a day, for 28 days in the preoperative period. The Experimental group was treated with nicotine [Nicotine Sulfate L-1 Metil-2 (3 Piridil)-Pirrolidine Sulfate; grade II; MW 422-6; SIGMA] injected into the subcutaneous tissue in a dose of 2 $\mathrm{mg} / \mathrm{kg}$, twice a day, for 28 days in the preoperative period ${ }^{11}$.

General anesthesia was administered by intraperitoneal injections of ketamine, and tiazine. Before the operation, the animals were positioned in dorsal decubitus, immobilized in a surgical table and submitted to depilation by manual traction. Antisepsis was made with iodine and the operating field was demarcated by sterilized dresses.
All animals were submitted to the TRAM flap procedure, with unilateral monopedicled rectus abdominis flap, caudally based on the right muscle preserving the right inferior epigastric artery.

The animals were returned to their individual cages for a period of 48 hours, after which they were reanesthetized as previously described. The area of necrosis was evaluated 48 hours after the TRAM flap procedure ${ }^{12,13}$. Standardized digital photographs of the flaps were taken. Photographs were scanned into a computer and area of skin necrosis was measured with the aid of image analyzing software IMAGE TOOL of the University of Texas Health Science Center in San Antonio. The area of the flap and its necrosis in square centimeters $\left(\mathrm{cm}^{2}\right)$ and percentage $(\%)$ were measured and tabulated. The animals were then submitted to euthanasia. Statistical analysis was performed with nonparametric Mann-Whitney's test, to compare percentage and area of necrosis in Control and Experimental groups, with $p<0.05$. The significant values were marked by asterisk $(*)$ indicating statistical significance. The mean and median were presented as additional information.

\section{Results}

In the present study, analysis of results demonstrated a greater area of necrosis in myocutaneous flap with the use of nicotine (Experimental group), compared to Control group (Table 1 and Figures 1 and 2).

TABLE 1 - Rats of Control (saline) and Experimental (nicotine) groups submitted to the TRAM flap procedure: evaluation of the percentage (\%) of necrosis (area of necrosis/ area of the flap X 100) and area of necrosis in square centimeters $\left(\mathrm{cm}^{2}\right)$

PERCENTAGE OF NECROSIS (\%)

CONTROL EXPERIMENTAL
AREA OF NECROSIS $\left(\mathrm{cm}^{2}\right)$

\section{CONTROL EXPERIMENTAL}

MANN-WHITNEY's test

(Control X Experimental)

\section{PERCENTAGE (\%)}

$\mathrm{Z}$ Calculated $=3.67 *(\mathrm{p}<0.001)$

Control $<$ Experimental

\author{
AREA OF NECROSIS $\left(\mathrm{cm}^{2}\right)$ \\ $Z$ Calculated $=3.96 *(p<0.001)$ \\ Control $<$ Experimental
}




\section{Control group}
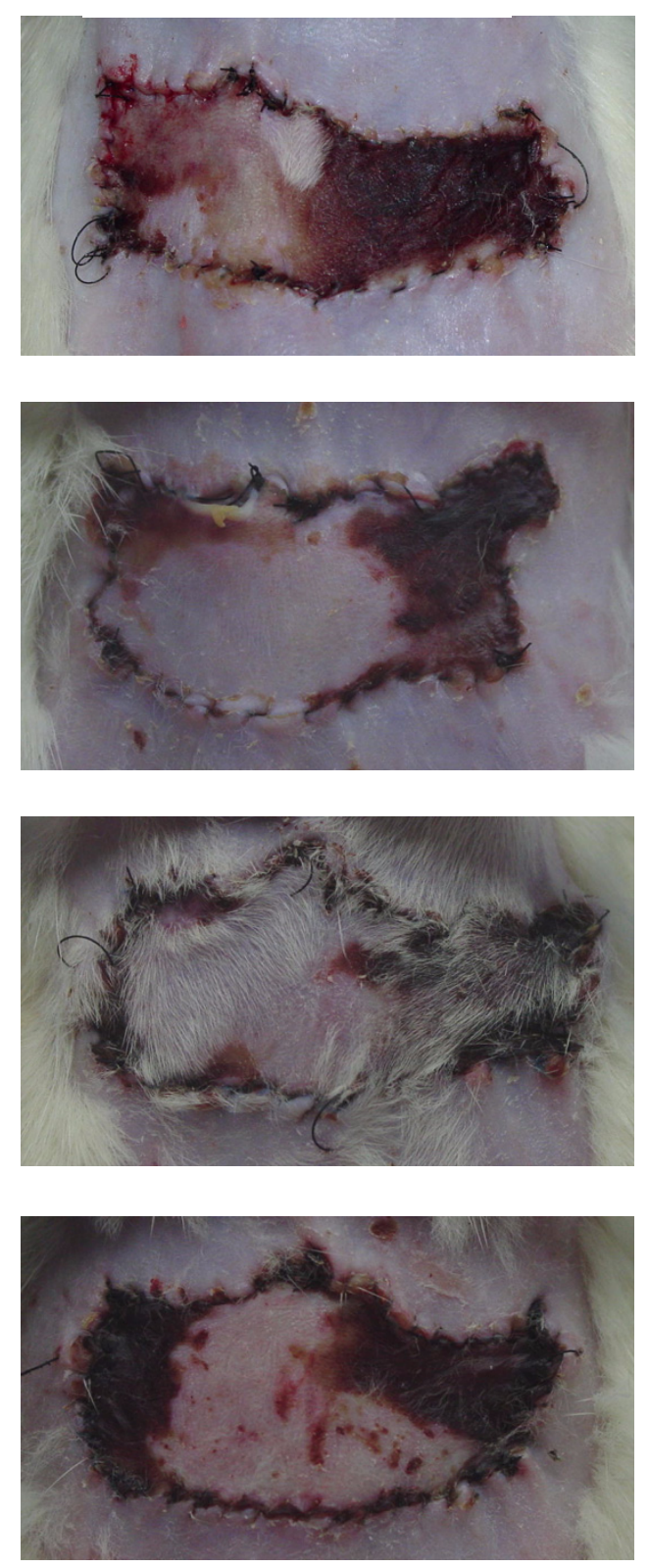

\section{Experimental group}
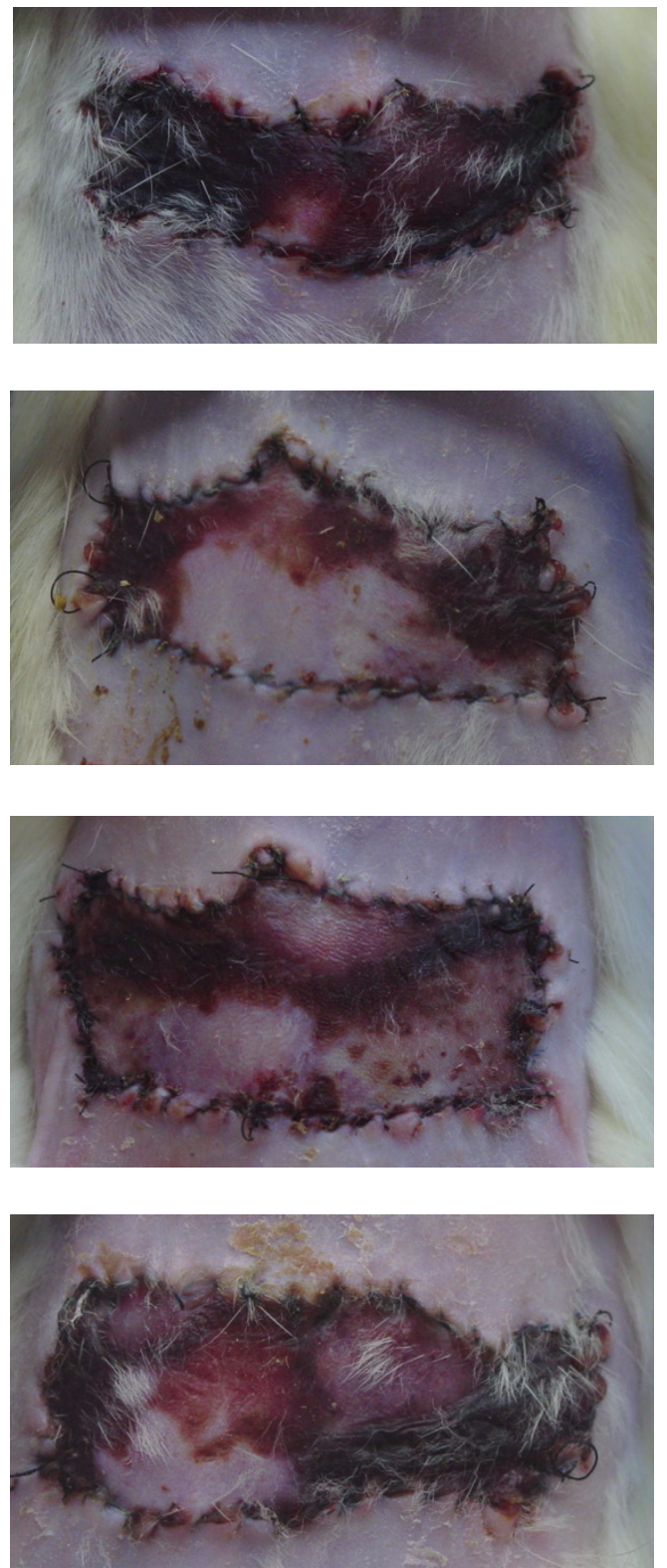

FIGURE 1 - Representative examples of the rat TRAM flap in Control (saline) and Experimental (nicotine) groups, showing the area of necrosis on the respective groups 


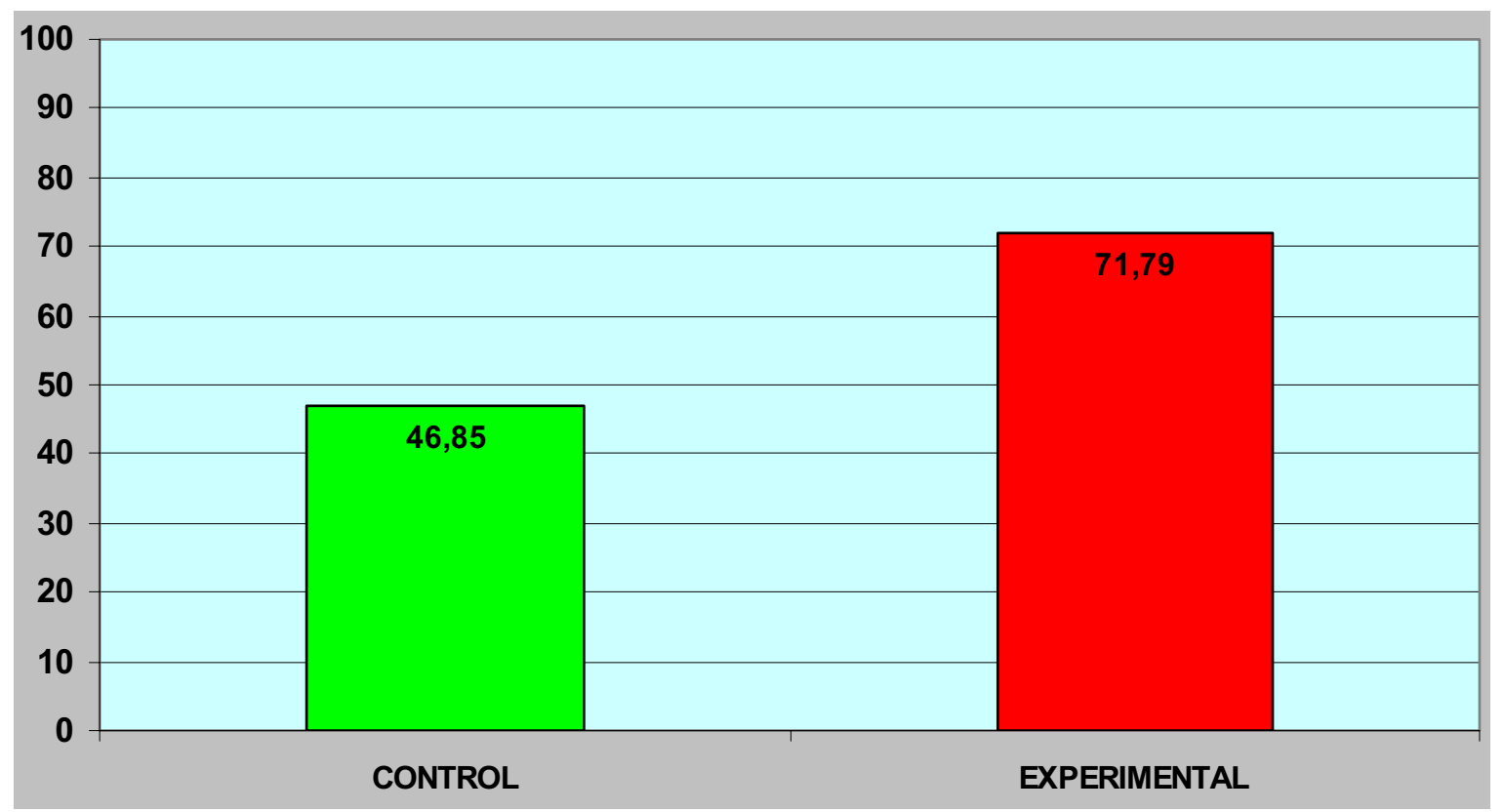

FIGURE 2 - Medium values of percentage (\%) of necrosis found in Control (saline) and Experimental (nicotine) groups

\section{Discussion}

Nicotine noxious effects on cutaneous flaps were discussed on clinical studies. Rees et al. ${ }^{10}$ related that a significant number of skin sloughs observed after face lift surgery are due to patient's cigarette smoking. Because an appreciable part of every surgeon's practice consists of smokers, the implications of this study, in terms of patient selection and pre-operative counseling, seem considerable. The deleterious effects of smoking on flaps have also been reported on clinical series by Kroll ${ }^{14}$ and Chang et al. ${ }^{15}$.

In the experimental field, Forrest et al. ${ }^{11}$ demonstrated a greater area of necrosis in cutaneous flaps with the use of nicotine, in rats. The deleterious effects of nicotine on random-pattern skin flap were studied by Campos et al. ${ }^{16}$, in rats; and also by Craig and Rees ${ }^{17}$, in hamsters.

Van Adrichem et al. ${ }^{18}$ studied the effect of cigarette smoking on the survival of free vascularized and pedicled epigastric flaps in the rat. Their findings demonstrated a greater area of necrosis on random vascularized cutaneous dorsal flaps in smoking rats. Smoking of cigarettes was detrimental to the survival of free vascularized epigastric flaps. However, Van Adrichem et al.${ }^{18}$ stated that the survival of the pedicled epigastric flap was independent of smoking. The present study obtained results that diverge from Van Adrichem et al. ${ }^{18}$, once nicotine augmented the area of necrosis of the rat TRAM flap.

In spite of the deleterious effect of the use of tobacco on skin and soft tissue flaps, and the significant morbidity associated to smoking in elective surgical procedure ${ }^{19}$, there is no standardization of management among plastic surgeons ${ }^{20}$. Rohrich et al. ${ }^{20}$ report the dilemma of plastic surgeons when they are asked to electively operate on patients that smoke, since there are no guidelines of conduct recommended based on research. Therefore, the necessity of more studies arises, to determine guidelines of conduct and counseling. The present work pursuits to collaborate in the comprehension of the problems inherent to the effects of nicotine in musculocutaneous flaps, setting the stage for further research.

\section{Conclusion}

Nicotine increased the area of necrosis of the TRAM flap, in rats.

\section{References}

1. Hartrampf CR, Scheflan M, Black PW. Breast reconstruction with a transverse abdominal island flap. Plast Reconstr Surg. 1982;69(2):216-24.

2. Dorion D, Boyd JB, Pang CY. Augmentation of transmidline skin perfusion and viability in transverse rectus abdominis myocutaneous (TRAM) flaps in the pig. Plast Reconstr Surg. 1991;88(4):642-9.

3. Losken A, Swartz MA, Van den Abbeele AD, Jain RK, Slavin SA. A potential murine model for flap-related investigations. Plast Reconstr Surg. 2001;107(6):1504-8.

4. Dunn RM, Mancoll J. Flap models in the rat: a review and reappraisal. Plast Reconstr Surg. 1992;90(2):319-28.

5. Ely PB, Ferreira LM. Transverse rectus abdominis musculocutaneous flap (TRAM flap) - experimental model in rats. Acta Cir Bras. 2003;18(spe):46-53. Available from URL:http://www.scielo.br/acb

6. Ely PB, Miltersteiner AR, Hoff FC. Retalho miocutâneo abdominal transverso de músculo reto abdominal (TRAM flap) - modelo experimental em ratos. Acta Cir Bras. 1997;12(Supl 2):75.

7. Özgentas HE, Shenaq S, Spira M. Development of a TRAM flap model in the rat and study of vascular dominance. Plast Reconstr Surg. 1994;94(7):1012-7.

8. Ely PB, Goldenberg S, d'Acampora AJ. Efeito da autonomização no retalho miocutâneo abdominal transverso de músculo reto do abdome, em ratas. Acta Cir Bras. 1999;14(Supl 2):25.

9. Forrest CR, Pang CY, Lindsay WK. Pathogenesis of ischemic necrosis in random pattern skin flaps induced by long-term low-dose nicotine treatment in the rat. Plast Reconstr Surg. 1991;87(3):518-28.

10. Rees TD, Liverett DM, Guy CL. The effect of cigarette smoking on skin-flap survival in the face lift patient. Plast Reconstr Surg. 1984;73(6):911-5.

11. Forrest CR, Pang CY, Lindsay WK. Dose and time effects of nicotine treatment on the capillary blood flow and viability of random pattern skin flaps in the rat. Br J Plast Surg. 1987;40:295-9. 
12. Sano K, Hallock GG, Rice DC. The relative importance of the deep and superficial vascular systems for delay of the transverse rectus abdominis musculocutaneous flap as demonstrated in a rat model. Plast Reconstr Surg. 2002;109(3):1052-9.

13. Seify H, Bulky U, Jones G. Effect of vascular endothelial growth factor-induced angiogenesis on TRAM flap harvesting after abdominoplasty. Plast Reconstr Surg. 2003;111(3):1212-6.

14. Kroll SS. Necrosis of abdominoplasty and other secondary flaps after TRAM flap breast reconstruction. Plast Reconstr Surg. 1994;94(5):637-43.

15. Chang DW, Reece GP, Wang B, Robb GL, Miller JM, Evans GRD, Langtein HN, Kroll SS. Effect of smoking on complications in patients undergoing free TRAM flap breast reconstruction. Plast Reconstr Surg. 2000;105(7):2374-80
16. Campos H, Ferreira, LM, Santos WLC, Araújo MCM. Efeitos da nicotina nos retalhos cutâneos em ratos. Acta Cir Bras. 2001;16 (4):206-10. 17. Craig S, Rees TD. The effects of smoking on experimental skin flaps in hamsters. Plast Reconstr Surg. 1985;75(6):842-6.

18. Van Adrichem LNA, Hoegen R, Hovius SER, Kort WJ, Van Strik R, Vuzevski VD, Van der Meulen. The effect of cigarette smoking on the survival of free vascularized and pedicled epigastric flaps in the rat. Plast Reconstr Surg. 1996;97(1):86-96.

19. Krueger JK, Rohrich RJ. Clearing the smoke, the scientific rationale for tobacco abstention with plastic surgery. Plast Reconstr Surg. 2001;108(4):1063-77.

20. Rohrich RJ, Coberly DM, Krueger JK, Brown SA. Planning elective operations on patients who smoke: survey of North American plastic surgeons. Plast Reconstr Surg. 2002;109(1):350-5.

\section{Correspondence:}

Cirurgia Plástica UNIFESP

Rua Napoleão de Barros $715,4^{\circ}$ andar

04024-002 - São Paulo - SP - Brazil

Phone/fax: (5511)5571 6579

sandra.dcir@epm.br

Conflict of interest: none

Financial source: none

Received: December 14, 2008

Review: February 18, 2009

Accepted: March 24, 2009

\section{How to cite this article}

Ely PB, Kobayashi LA, Campos JHO, Gomes HC, Juliano Y, Ferreira LM. Nicotine on rat TRAM flap. Acta Cir Bras. [serial on the Internet] 2009 May-Jun;24(3). Available from URL: http://www.scielo.br/acb

Color figures available from www.scielo.br/acb 